\title{
Oxidizing Enzymes of Sugarcane: Peroxidase
}

\author{
Alex G. Alexander 1
}

\section{INTRODUCTION}

Although a ceniury has passed since peroxidase was first recognized in plinuts $(3 / 4),{ }^{2}$ its specifie roles have been obscured by the large number and diversily of potential substrates. By the type reaction

$$
\mathrm{AH}_{2}+\mathrm{H}_{2} \mathrm{O}_{3} \rightarrow \mathrm{A}+2 \mathrm{H}_{2} \mathrm{O}
$$

where $\mathrm{AH}_{2}$ Jepresents an electron donor and hydrogen peroxide the at:reptor, numerous phonols, aromatic amines, and other compounds can be oxidized, themselves becoming potential oxidants of additional substances. Thus peroxidase has been pul forward as a constituent of terninal oxidution ( $t$ ), as an agent in the oxidation of metabolites by neans of $\mathrm{H}_{2} \mathrm{O}_{2}$ by product $(16, p .364)$, and as a key component of the indoleacetic acid oxidase system (39,27). More recent tindings implicate peroxidase in the formation of anides $(18,28)$.

Peroxidase has been found in numerous plant species which include the fig tree (8/), corn (27), cucumber (18), cilrus (28), tomato (7), cauliflower (3), and sugarcune $(1,2)$. However, the greatest advances toward understanding the physical and chemical properties of peroxidase have becn made with the horseradish enzyme purified by Willstatter et al. $(40,39)$, and crystallized by Theorell (38). It is a motalloporphyrin-protein with a molecular weight of about 40,000 . The protein portion is itself inactive moless conjugated with hemin, which, in turn, makes up 1.47 perceut of the horseradish enzyme. Peroxidase has been likened to methemoglobin $(16,13.363)$, both proteins bearing iron in the ferrie state.

Is an iron-requiring enzyme, peroxidase belongs to "a "fanily" of metalcontaining "atalysts broadly classified as "oxidases"." Bearing a common capneity to stimulate the passage of electrons from donor to aceeptor, the enzymes cutalase (iron), cytochrome-c oxidase (iron), ascorbic acid oxidase ('opper), and tyrosinase (copper) join peroxidase as potential catalysts of respiratory reartions. Many dehydrogentises also fall under the heading of oxidases. Thowe that are best known do not contain specific metals,

I Associnte Plant Pliysiologist, Agrienllural lixperiment Station, Lniversity of I'uerto Rico, Rto Piedriss, P'.R.

2 Talic numbers in parentheses refer to Literalume ('ited, pp. 50-2.

${ }^{3}$ Oxidation ean be defined as: 1 , Addition of oxygen or a hydroxyl; 2 , loss of dy. drogen; and 3, loss of electrous. Since the oxidation of one substance nsmally mens flatt another substance is being reduecel, the "reduclases" may he vicwed as catalyzing the reverse of oxidation. 
although sone have common requirenents for riboflavins or for coenzymes I and II.

The necessity of iron for notmal peroxidase activity has led to the study of this enzyme as a possible indicator of iron deficiency in agrieulturnl crops. Brown and Hendricks (7) found that plants grown on iron-deficient; soil exhibited a greally weakented peroxichse activity as compared with that of plants recoiving an adequa iron supply. Brown and Steinberg $(6)$ reported low peroxidase activity anong iron-deficient tobacco plants. Similar iron-peroxidase relat ionshiys were observed with cauliflower grown in saud culture (3).

Peroxidase of sugareane hats not deceived the close attention given to enzymes more obviously related to sugar syuthesis and degradation. Nerertheles, a strong peroxidase leation has ben observed in cane, and, curiously enough, this enzyme exhibited an almost perfectly inverse dela tionship with changing sucrose levels induced by variable nitrate supply (1). A similar peroxidase-sucrose correlation was later encountered among plames treated with indole-3-acetir acid (2). This paper summarizes in vilo properties and behavior of cane peroxidase as an initial effort toward clarifyiug the relationships between sucrose content and oxidizing enzymes of rane.

\section{MATERIALS AND METIODS}

Euzyme preparations were nade with leaves +1 to $+4,{ }^{1}$ from the varicty MI.336, which had been frozen, freeze-dricd, and ground to pass a 60 -mesh scleen in accordance with procedures describes eurlier (I). Six grams of the dried powder, representing about $30 \mathrm{gm}$. of fresh material, were $\mathrm{x}$ tracled l'or 30 minules at $20^{\circ} \mathrm{C}$. in distilled wator or phosphate buffer. The extraction was facilitaled with a mechanical shaker operating at high speed. Extracts were clarified by expression through four layers of cheesechoth, followed by centrifuge at 3,000 r.p.m. The p.H was adjusted to 7.0 with $0.2 \mathrm{~N}$ NaOH and suffieicnt solid ammonimm sulfate was added to achicse 95-percent satuation. 'This was acromplished over a 10-minute period with constant slinding of the solution. The precipibated protein was renoved by centrifuge and taken $u$ ) in $5 \mathrm{ml}$. of dis(illed water. The protein solution was clarified and refrigerated at $2^{\circ}$ C. Appropriate dilutions were made just prior to runuing peroxidase assays. Mfaximum activity was obtained without dialysis.

The peroxidase assicy is based upon the formation of purjurogallin in it buffered mixture of pyrogallol, peroxide, and enzynte. ${ }^{5}$ The resultiunt yellow rolor is measured spectrophotounctrically at 4:30 $m \mu$.

\footnotetext{
4 Peroxidase was also obtrined liron meristem, leaves -1 and 0 , leaves +2 and +3 ,

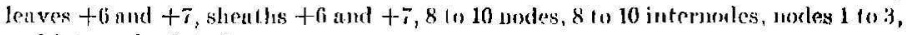
and inleriodes 1 to 3 .

"This prosedure is derived from the standurd assity of Willstaller ef at. (40, 39),
} 
<smiles>O=C1c2cccc(O)c2-c2c(O)cc(O)c(O)c21</smiles>

Purpurogallin

The standard reaction mixture for peroxidase was composed as follows: One milliliter of 0.1 . II (molar throughout) phosphate buffer, $p \mathrm{H} 7.2$, was placed in duplicate 1-cin. pyrex cuvettes, followed by $0.5 \mathrm{ml}$. of 0.3 -percent hydrogen peroxide. Approximately 5 units of enzyme were added to each curette. Reference conpositions received distilled water in place of peroxide. After adding $1 \mathrm{mI}$. of $0.5-\mathrm{M}$ pyrogallol to the control vessel, the optical-clensity reading was adjusted to zero, pyrogallol was added to the test cuvette, and a stopwatch started immediately. Readings were agajn taken for both test and reference vessels after 1 minute had passed. Since pyrogallol is slowly oxidized by the enzyme preparation in the absence of peroxide, the final peroxidase reading was obtained by subtrarking the control value from that of the test composition.

One peroxidase unit was arbitrarily defined as the amount ol cuzynue causing an optical density increase of 0.10 per minute under the preseribed conditions of the assay. Peroxidaso action is expressed as specific alclivity, i.e. units per milligram of protein. Protein content of the enzyme preparattions was metsured colorimetrically by the method of Sutherlaud ot al. (35), or by dry-weight determinations of ovendried samples.

Before continuing with a discussion of cane peroxidase, it must be emphasized that the cuzyme malues recorded here are relative, or "apparent," rather that absolute activity measurements. Peroxidase forms at least three compounds with hydrogen peroxide $(21,9,10,11)$. All intermediate enzyme-peroxide complex is formed enzymatically prior to the reaction with the electron flonor molecule, pyrogallol. Two reactions nust therefore be considered, and, since the first can be completed beiore all of the product has been formed $(1 /, 7.770)$, the appearance of purpurogallin is not actually a direct measure of peroxidase activity.

\section{RESULTS AND DISCUSSION}

\section{LYTRACITON, FRACTIONATTON, AND DISTRIBUTION}

Some success has been gained at this Iaboratory by pretreating leaf and sheath suspensions by sonification prior to extraction. Yields of $\mathrm{Q}$ cnzyme

who developed one of the few satisfactory techniques for mensuring peroxidase. The procedure described here employs a sinaller volume of reagents, direct mensurement of proluet, and a shorter reaction period. 
(4) and inctase (5), in particular, were increased by subjecting the chilled suspensions $\left(0-14^{\circ}\right.$ C.) to sonic disintegration for severnt minutes. However, similar treatments were negative with regard both to peroxiclase and total

TAви; 1.- Extraction of cane peroxilase and protein following preltealment of leaf-povder suspensions by sonic disintegration

\begin{tabular}{|c|c|c|c|c|c|}
\hline \multirow[b]{2}{*}{ Data classification } & \multirow[b]{2}{*}{ Treatment } & \multicolumn{4}{|c|}{ Data for solvent indicated ${ }^{1}$} \\
\hline & & $\begin{array}{l}\text { Acetilte } \\
\text { buffer } \\
\text { (pII } 4.65 \text { ) }\end{array}$ & $\begin{array}{c}\text { Acetale } \\
\text { buffer } \\
\text { (pH } 5.50 \text { ) }\end{array}$ & $\begin{array}{l}\text { Distilled } \\
\text { water }\end{array}$ & $\begin{array}{c}\text { Phosplate } \\
\text { bufier } \\
\text { (pH 7.0) }\end{array}$ \\
\hline \multirow[t]{2}{*}{ Peroxidase? } & With sonitier & 9.5 & 25.7 & 6.4 & 6.1 \\
\hline & Without sonifier & 12.8 & 27.4 & 31.4 & 21.7 \\
\hline \multirow[t]{2}{*}{ Tolal protein ${ }^{3}$} & With sonifier & 2.74 & 2.80 & 1.66 & 1.70 \\
\hline & Without soujfier & 2.00 & 3.76 & 2.90 & 6.60 \\
\hline
\end{tabular}

${ }^{1}$ Buffer eoncentrations were $0.1 \mathrm{M}$.

${ }^{2}$ Expressed as specific activity.

${ }^{3}$ Expressed as milligrams per gran of dry weight.

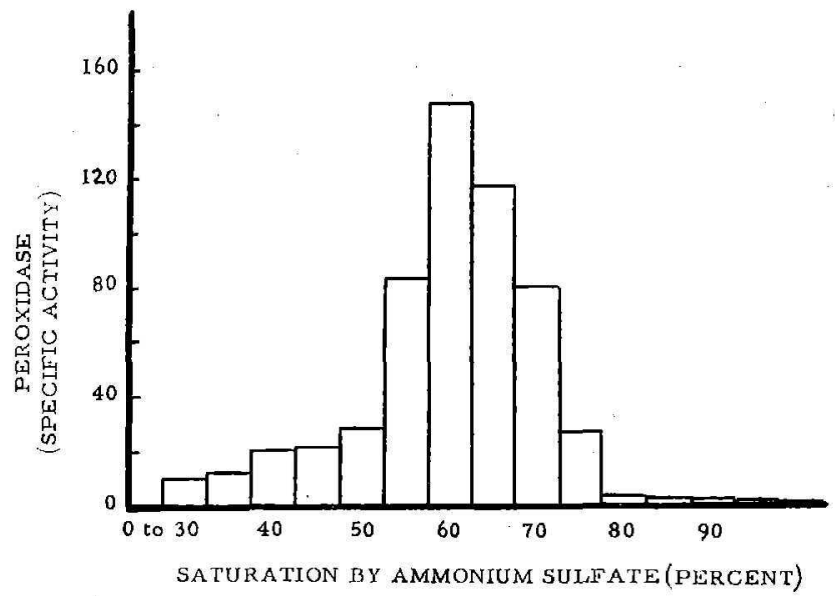

Fuc. 1.-Peroxiduse activily among protein inerements precipita ted by ammonium sulfate from extracts of sugarcane leaves.

protein during the present study (table 1). The sonifier vas apparently quite destruetive of protein when distilled water or phosphate buffer was used for solvents, as evidenced by low protein yield and retarded enzyme activity. Phosphate buffer was the most satisfactory solvent tested. 
Fractionation of the ranc-Inat extricts by ammonium sutfate revesled that most of the peroxidase was presipitated between 50 - and 70 -perent saturalion (fig. 1). This fraction, which was enployed during (he renainder of the study, also combaned large quantilies of anylase and phosphatatse.

Distribution of peroxidase within the plant was ascertained with a series of tissue samples taken from 10-month-old cane of the ratiety Tha Marot. (table 2). Easily the greatest speeific activity was recorded with proparalions from leaves +6 and +7 , and from sheaths +6 and +7 . Honerer, activity expressed on a dry-weight basis showed that meristom linstues hate the highest jeloxidase content. The same observation has of ten besn malde with sugareane, the moristen having extrenely high enayne adivity, albeit only a snall fraction of the plant is represented by this fissut.

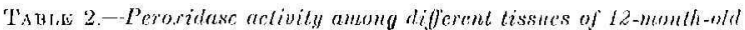

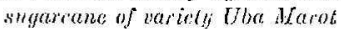

\begin{tabular}{|c|c|c|c|c|c|c|c|c|c|}
\hline \multirow[b]{2}{*}{ Diata classibication } & \multicolumn{9}{|c|}{ Data for tissue souree indicated } \\
\hline & Meri- & $\left\{\begin{array}{c}\text { I,eaves } \\
(-1 \\
0)\end{array} \mid\right.$ & $\begin{array}{l}\text { Lecitwes } \\
(+2 s \\
+3)\end{array}$ & $\begin{array}{c}\text { Leaves } \\
(+0 \& 4 \\
+7)\end{array}$ & $\begin{array}{c}\text { Sheaths } \\
(+6 \text { \& } \\
+7)\end{array} \mid$ & $\begin{array}{l}\text { Norles } \\
(9-10)\end{array}$ & $\begin{array}{l}\text { Inter- } \\
\text { nodies } \\
(8-10)\end{array}$ & $\begin{array}{l}\text { Sodes } \\
(1-3)\end{array}$ & $\begin{array}{l}\text { Inter- } \\
\text { nodies } \\
(1-3)\end{array}$ \\
\hline Specifie netivity & $10 \pi .9$ & 107.8 & $1+2,0$ & 202.1 & $216 . f^{i}$ & 71.3 & 56.2 & 78.9 & $10 \mathrm{j} .1$ \\
\hline $\begin{array}{l}\text { Pcroxidase units per } \\
\text { gram of tissue }\end{array}$ & 192.0 & +4.8 & 70.0 & 05.0 & 72.5 & 28.5 & 18.2 & 28.0 & 26.5 \\
\hline
\end{tabular}

PROPWRTIES OF SUGARCANE PEROXIDASE

Slabilily

Stability of cane peroxidase was tested at several temperatures, ineluding room $\left(27-29^{\circ} \mathrm{C}.\right)$, Laboratory $\left(19-21^{\circ} \mathrm{C}\right)$, and refrigerator $\left(2^{\circ} \mathrm{C}.\right)$. All samples were stored under loluene. Tuble 3 indicates that, the enzyne lost much of its catelytie cajarily within 48 hours of extraction, but that it was still readily measureable afier 12 days. This decline was more pronouned anoug defrigerated samples than those stunding at laboratory temperature. This is unusual behavior lor an cnzyme. Henceforth peroxidase samples wero prepared daily.

Peroxidase preparations revealed a dofinite recuperative capacity after having been boiled for 5 minutes. Whereas no aclivity was evident inmediately after boiling, 13 percent of the original activity returned aller 10 minutes, 32 percent withiu 30 minutes, and a uximum of 42 percent after 3 hours. According to Summer and Somers $(3.4$, p. 223), boiled crude preparations may degain some netivity upon standing, whereas purified horseradish peroxidase is not seriously affected ate all by boiling. Regencra- 
tion of activity has been linked with the presence of cytochrome-s in the tissues (31).

\section{Optimum Temperatu'e and $p H$}

Cane peroxidase was tested at temperalures ranging from 16 to $52^{\circ} \mathrm{C}$. Since no satisfactory methor is available for regulating temperatures of test solutions within the spectrophotometer employed, the following procedure was adopted: Duplicute test Lubes coulaining all components of the stundard digest, exiept stubstrate, wore equilibrated for 5 minutes in a water bath adjusted to the desired lemperalure. P'yrogallol solutiou was equilibruted scparatoly. The reaction was iniliated by transferring $l \mathrm{ml}$. of substrate to the test and reference solutions. Two minutes wore allowed for the reaction to proceed. Contents of the test ubes were rupidly transferred to 1-cm. cuvettes where optical-density differences between control and

TABLE 3.-Specific-activity decline of cane peroxidase preparations stored at variable temperaturcs ${ }^{1}$

\begin{tabular}{|c|c|c|c|c|c|c|}
\hline \multirow{2}{*}{ Storage temperalure: } & \multicolumn{6}{|c|}{ Sipcific uctivity on days collowing preparation inrlicatcal } \\
\hline & () & 2 & & $t$ & 8 & 12 \\
\hline lioum $(27 \cdot 29)^{\circ}(1)$ & 26.2 & 17.5 & ! & 15.0 & 13.7 & 11.2 \\
\hline Lithortilory $\left(19-27^{\circ} \mathrm{C}()\right.$. & 26,2 & 22,2 & i & 20.0 & 16,3 & 12.2 \\
\hline liclirigrritor $\left(2^{\circ} \mathrm{C}\right)$ & 26.2 & 18.7 & & 16.2 & 10.0 & 10.0 \\
\hline
\end{tabular}

1 The standiard peroxidase procedure was used for all texis.

test solutions were determined ns usual. About 2 minutes and 15 seconds elnpsed for each renction. Although some error was unaroidable, the results: are nevertheless relative and showed that the optimum temperalure for this enzyme is about $36^{\circ} \mathrm{C}$. (fig. 2,A). The luboratory temperature usually employed for proxidase $\left(20^{\circ}\right.$ C.) permitted an aclivity somewh less than half of that recorded at $36^{\circ} \mathrm{C}$.

Optimum $\mathrm{pH}$ is about 7.4 (fig. $2, \mathrm{~B}$ ).

\section{Km and Optimum Peroxide Concentration}

A practical defnition of the "Michaselis constant" $(\mathrm{Km})$ in that it is the substiate concentration af half muxinum velocity $(29,1$. :8). Sugartane peroxidase achieved a lineur reaution up to 5 mmoles of pyrogallol per millilitor of digest (fig. 3, $\Lambda$ ). Insofar as it is anplinable to the poroxidase? reaclion, the apparent $K \mathrm{~m}$. thus becomes $2 . j \times 10^{-3}$ moles of pyrogallol jer liter.

Maximum peroxidase velocity was oblained with 1 mmole of hydrogen 
peroxide per millititer of digest (fig. :3,[3). However, some activity increase could he gatined by lating the peroxide concentration to as much as 140 umoles/mL. l'ossibly a number of peroxidases exist in cane, some of which
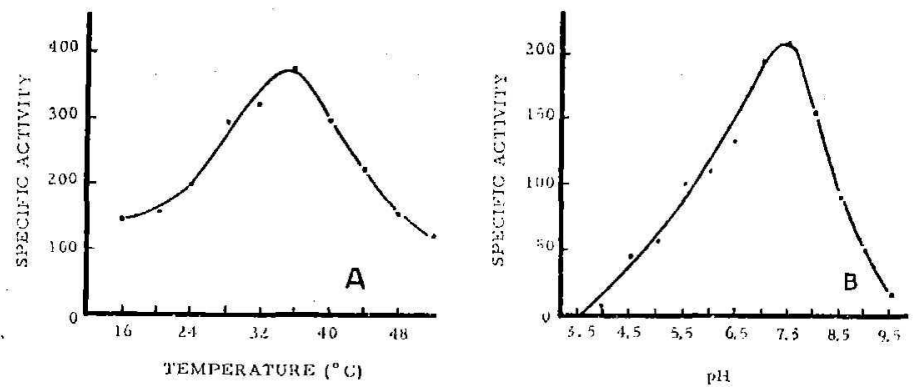

Fici. 2.-A, Enects of temperature on cane peroxidase uctivity; phosphate buller (pH 7.2) was used with standard assay. B, Efleetis of pH on cane-peroxidase activity; all reactions were run $u 1.22^{\circ} \mathrm{C}$, according lo standard assay, in conjunction with $0.1-\mathrm{M}$ concentrations of the following bulfers: Acetate, pH $3.5-5.5$; succinate, pHt (i, ()-7.0; and tris (trishydroxymethylinian methane), pH 7.5-9.5.
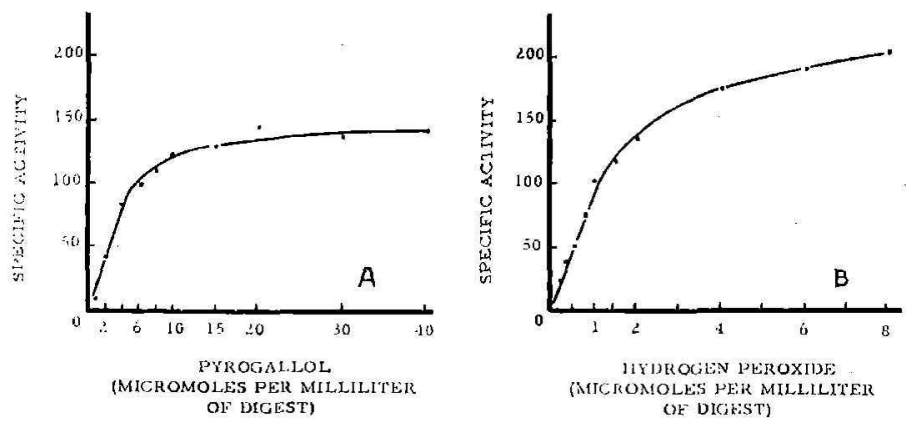

Fid. 3. - A, Pyrogallol requied for optimum activity of calue peroxidase. Standard thigest was used with varinble pyrogallol. $B$, Saluration of tane peroxirlaze by hydrogen peroxide. Standard digest was employed throughout with variable peroxide.

rontinue to strive for saluation with peroxide long after this has beren arelieved for the prineipal emyruse.

\section{Reaction Velocity v's. Time and Enzyme Concentration}

The standated assay herein employed measures peroxidase from the time pyrogallol in adcled to tho digest. Since both euzyme and peroxide were 
previously combined in the reaction mixture, the initial phisses of the peroxidase reaction are already underwny, i.e. the formation of enzyneperoxide complexes. For this reason, plus the fact that the initial reactions are supposedly rapid and not considered to be rate-limiting $(3.4$, p. 222), pyrogallol formation should be plotted as a typical diphasic reaction. This does in fact oceur for cane peroxidase (fig. $4, \mathrm{~A}$ ). Under conditions of the stundard assay, a zero-order reaction is maintained slightly less than 2 minutes, with a first-order renetion continuing at least up to 5 minutes.

Peroxidase prejuations were diluted during this study so that between 4 and 6 units were ordinarily present in the reaction mixture. A linear relationship cxisted between reaction volocity and enzyme content to it rencentration of at least 12 units per dignet, (fig. A,B).
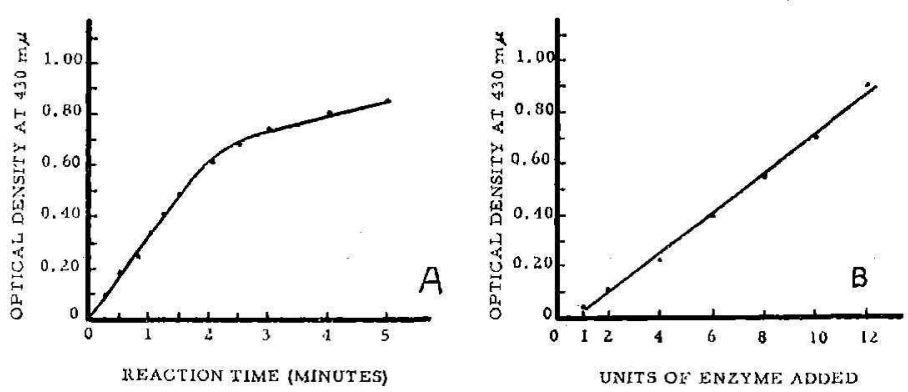

Fig. 4,-A, Proportionality of peroxislase activity with time; five units of enzyme were used. B, Proportionality of activity with enzymr concentration; units of enzyme arc indicaled.

\section{Substrate Specificily}

As pointed out earlier, a large number of compounds may loe oxidized by various peroxidases, while the products, in turn, may oxidize other substances. Sumner and Somers $(3,4, p .221)$ list 14 compounds subject to the action of plant peroxidase in the presence of $\mathrm{H}_{2} \mathrm{O}_{2}$. Sugntenene peroxidase gave positive reactions with the following compounds: Orthoesesol, hydroquinone, catechol, pyrogullol, benzidine, antaline, tryptophane, guaiacol, and gum arabic. Other substances can undoubtedly ser' 2 in the cane: peroxidase reaction.

\section{Activalion ctnd Inhibition}

A series of entions and unions were tested for possible regulatory eflects upon peroxidase (table 4 ). Also lested were $\beta$-glycerophosphate, thiourea, glucose, and hydroxylanine. All additives were employed at the rate of 1 
pmole/nul. of digest. When tested in strotdane with the standard assity, the additives ropper and nolyhdenum each inpeared to stimulafe peroxidase. This was actually aused by a nouenzymalde oxidation of pyrogallol in the presence of addilive and hydrogen peroxide. Iodide more than doubled peroxidase activity as the only true activalor encountered.

Calciun, manganese, and zinc cach caused a moderate suppression of the sugarcane enzyme. Hydroxylamine markedly ituhibited this leaction, in agreement with Sumner and Somex's statement regarding horseradish feroxidase (it, p. 22:3). In contrast to the horseradish enzyme, however,

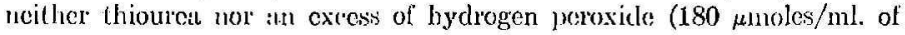
digesi) raused inhibition.

\begin{tabular}{|c|c|c|c|c|c|}
\hline Arlilitive & $\begin{array}{l}\text { Snecific } \\
\text { in:livity }\end{array}$ & Additiver & $\begin{array}{l}\text { Sinecitic } \\
\text { aclivily }\end{array}$ & Additive & $\begin{array}{l}\text { Specifit } \\
\text { aelivity }\end{array}$ \\
\hline I.K) (anontrol) & 1.12 .5 & I & 350.0 & $\% 11$ & 126.3 \\
\hline$M_{\mathfrak{L}}$ & 127.5 & As & 1.50 .0 & Thinurea & 111.3 \\
\hline C:a & 115.0 & C:u & - & Nitrates & 132.5 \\
\hline B & 121,3 & $\mathrm{M} n$ & 103.8 & $\beta \cdot$ glucerophosphato & 147.5 \\
\hline $\mathrm{r}^{2}$ & 121.3 & Mo &. & Gilueose & $1: 16.3$ \\
\hline $33 \mathrm{r}$ & 130.0 & K(:X) & $15 \mathrm{t} .3$ & Hydinxylamine & 58.8 \\
\hline
\end{tabular}

1 Each additive was supplied at the rate of $1 \mu \mathrm{mole} / \mathrm{mL}$. of digest, The standard reaction was employed throughout with supplomental materials taking the plase of rlistilled wuler.

\section{Dialysis}

No effect was noted upon eane ycroxidase activity following 36 hours of dialysis against distilled water. No dialysis effects were anticipated, since the nomprotein romplement (hematin) is tightly bound to the protein and cannot be removed by other than extraordinary means (36).

\section{Mechanism of Peroxidase Action}

It was mentioned eatier thit at least two phases are involved in the peroxidase reastion, including the formation of enzyme-peroxide complexes, and the transer of electrons from a donor molecule to peroxide. Whereas the chemical changes undergone by peroxidase (horsertdish) during its ratalytic processes have not been chuified in detail $(2 i, 1 \gamma)$, the work of Chance $(9,10,11,18)$ points with certainty toward the formation of at least thrce enzyme-peroxide complexes. Peroxidase reactions can thus be summarized as follows ${ }^{6}$ :

$$
\text { 1. Peroxidnse- } \mathrm{H}_{2} \mathrm{O}+\mathrm{H}_{2} \mathrm{O}_{2} \stackrel{K_{1}}{\rightarrow} \text { Peroxidase- } \mathrm{H}_{2} \mathrm{O}_{2}+\mathrm{H}_{2} \mathrm{O}
$$

- AH. denoles a hall-oxidized electron-clonor moleculd. 
$\kappa$

2. Complex $\mathrm{I}+\mathrm{AH}_{3} \rightarrow$ Complex $\mathrm{II}+\mathrm{AH}+\mathrm{H}_{2} \mathrm{O}$

3. Complex II $+\Lambda H .+\Lambda \mathrm{H}_{2} \stackrel{K_{4}}{\rightarrow}$ Peroxidase $-\mathrm{H}_{2} \mathrm{O}+\mathrm{A}+\mathrm{AH}_{3}$

Complex III is formed from complex II in the presence of excess hydrogen peroxide. It is stable und does not oxidize the substrate. When observed spectroseopically, complex I is grem, complex II is pale red, and romplex III is bright: rod.

It is assumed that canc peroxjdase talses part in reactions sinilat to those given athove for the homeralish mzyme. This all be denonstraled by

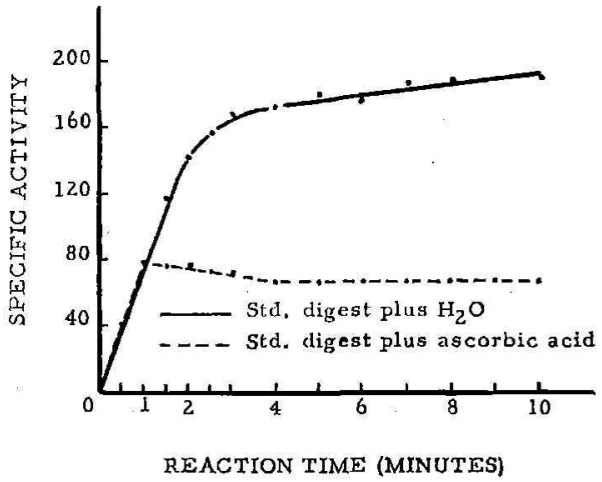

FIC. 5.- - Inhibitury olfertis of ascorbic acid on cane peroxidase: ancorbic arid wats added in 1 of 2 digests, after 1 minute had chapsed, in sufficient concentration to make $10 \mu$ mole/ml. of digest.

urcoupling the reaction sequenes wilh a readily oxidizable substance. For example, each of the thee compounds should rapidly disanpeur in the presence of ascorbic acid, with the concurrent formation of free mayme plus dehydroascorbic acid. Stabilization of purpurogallin content in the reaction mixture would follow immediately. Figure 5 illustrutes the retarding effect of ascorbic acid upon sugarcane peroxidase, including : slight loss of purpurogallin during the 2 minutes following ascorbic acid incorporation. This was possibly caused by a modcrate reversal of reaction 3 above, which would necessitate the constant $K_{5}$, although enzymatic oxidation of the donor molecule is not generally regarded as reversible.

Two rate constants need to be distinguished in order to cvaluale the catalytic potential of peroxidase, including the velocity constant for the formation of an enzyme-substrate complex, 


$$
\mathbf{E}+\mathrm{S} \stackrel{K_{\mathbf{I}}}{\rightarrow} \mathbf{E S},
$$

and the velocity constant for the reaction of a secoudary complex (complex 2) with the electron donor molecule,

$$
\mathrm{ES}_{11}+\mathrm{AH}, \stackrel{K_{1}}{\rightarrow} \mathrm{E}+\mathrm{P}
$$

$K_{1}$ and $K_{4}$ of sugarene peroxidase were estimated by the "guaticol test." Developed by T. X. Devlin and described in detail by Chance and Maehly (1/4), the procedure is based on the principle that poroxide utilization $(d x / d l)$ depends upon the respective concentratious of peroxide and guaiacol in the following manner:

$$
\frac{d x}{d t}=\frac{e}{\frac{1}{K_{4} a_{0}}+\frac{1}{K_{\mathrm{r}} x_{0}}}
$$

where $\theta=$ concentration of enzyme.

$a_{0}=$ initial concentration of donor.

$x_{0}=$ initial concentration of substrate.

$K_{1}$ is determined under carcfully prescribed conditions in which $K_{4} a_{0} \gg$ $K_{2} x_{0}$, and $K_{4}$ is determined by adjusting the assay so that $K_{1} x_{0} \gg K_{1} a_{0}$. Fuzyne concentration was estimated colorimetrically (35) and by dryweight determinations of ovendried simples. Dry weight of enzyme used was divided by the molecular weight of peroxidase $(40,000)^{7}$ to obtuin $\epsilon$. Where $\mathrm{x}=7.5 \mu \mathrm{mules}$ of $\mathrm{H}_{2} \mathrm{O}_{2}$, and $t=$ the measured time interval to achieve an optical density increase of 0.050 at $470 \mathrm{m \mu}, K_{1}$ and $K_{1}$ were r'ilculated as follows:

$$
K_{1}=\frac{1}{x_{0} t} \times \frac{\Delta x}{\Delta t}=\frac{7.5 \times 10^{-6}}{3.3 \times 10^{-5}} \times \frac{1}{e \Delta t}=\frac{0.22}{e \Delta t}
$$

The experimental value for $K_{1}$ was $0.13 \times 10^{7} \mathrm{M}^{-1} \times \mathrm{sec}^{-1}$ at $20^{\circ} \mathrm{C}$,

$$
K_{1}=\frac{1}{a_{0} e} \times \frac{\Delta x}{\Delta t}=\frac{7.5 \times 10^{-6}}{3.3 \times 10^{-4}} \frac{1}{x e \Delta t}=\frac{2.2 \times 10^{-2}}{e \Delta t}
$$

The computed $K_{4}$ value was $0.46 \times 10^{5} \mathrm{M}^{-1} \times$ sec. $^{-1}$ at $20^{\circ} \mathrm{C}$.

Under identical test conditions, pure horseradish peroxidase has $K_{1}$ and

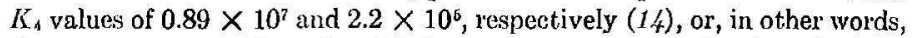
these constants are about 7 and 5 times greater, respectively, than those for unpurified cane peroxidase. This difference is undoubtedly attributable to

7 Theorell (97) placed the molecular weight of horseradish peroxidase at 40,200 , whereus Cecil and Ogston (8) reported a value of 39,800 . 
Whe fact that a mixture of enzymes composed the sugarcane preparation rather than a pure cutalyst. It is also inportunt that the assay conditions of the gualacol test have been worked out with precision only for holserudish peroxidase.

Nevertheless it is evident that oxidation of the donor molecule proceeds far les; lapidly than the initial formation ol an enzyme-peroxide complex. Hence, complex II may be regarded as the "Michnelis compound" (rals: detemining) of the peroxidase calalysis, and oxidntion of donor as the true rate-limiting reaction.

\section{Physiological Significance of Peroxidase}

The potential of peroxidase to affect plant physiology is so broud that, for ycars, little more than generulizations were suggested to account for this enzyme. Thus Sumner and Somers $(34$, p. 222) suggesled that, through the oxidation of phenols and ferrocy tochrome-c, peroxidase might play a role in terminal oxidation, but little experimental evidence was available to support this point.

Keilin and Fartree (2Q) demonstrated that, if culalase und ethanol ar" added to a system in which $\mathrm{H}_{2} \mathrm{O}_{2}$ is produced, the alcohol is oxjdized to acel aldehyde:

$$
\mathrm{CH}_{3} \mathrm{CH}_{2} \mathrm{OH}+\mathrm{H}_{2} \mathrm{O}_{2} \rightarrow \mathrm{ClH}_{3} \mathrm{CHO}+2 \mathrm{H}_{2} \mathrm{O}
$$

'This corresponds to the type of reaction catalyzed by peroxidases, indicating a similarity of action belween these and the catalases. ${ }^{8}$ The two types of enzynes are thus considered to belong to a single group, the "hydroperoxidases," with each of the enzyme types exhibiting specificity proferences for the dectron donor molecule.

Peroxidase has been implicated strongly in the miniainance of auxin levels in plants. It is regarded as the effective component of indoleacetic acid oxidase (39). McCune (27) reported that corn contains several peroxi dases which differ in their capacity to take part in the indolearetic acid oxidase system. Investigations by Halevy (18), and by Monsclise and Halevy (28), revealed that the growth-retarding compound "Amo-1618" increased peroxidase activity in seedlings of cucumber and citrus. It was proposed that growth retardants affect the auxin level of plant tissues by promoting auxin destruction. This concept was vindiented during later studies by Halevy (19), when it was found that; five growth-retarding compounds stimulated indoleacetic acid oxiduse and peroxidase in hypocotyl tips and cotyledons of cueumber scedlings grown in darkness. This effect was inversely correlated with hypocotyl elougation effects of the same

${ }^{8}$ Since $\mathrm{H}_{2} \mathrm{O}_{2}$ is toxic to living systems, it was long thought that the prineiple function of catalases was to destroy $\mathrm{H}_{2} \mathrm{O}_{2}$, 
chemicals. Halcvy suggested that growth retardants exert their effect on Jlant growth by interatiug wilh gibberollin in indoleacetic acid oxidatse, or its colactors and inhibilors.

A different but highly important function of peroxidase was suggested by the work of Mazelius and Inguaham $(26,25)$. These investigators studied the oxidntive decarboxylution of methioune by horseradish peroxidase and found that the produst was an amide (3-snethylthiopropionamide). Traditionully, the enzymatic formation of primary andes has involved the activation of $\mathrm{NH}_{3}$ (\%) or the transfer of an anino (23) or amide gromp (30). Ureido compounds, having anjde charaser in vicw of their--CONH, groujs, likewise oceur by $\mathrm{NH}_{3}$ aretivation (20) or by pyrinidine and purine degradation $(15,32)$. The report of Mazclis and Ingrahan (25) was the second to review anide formation directly from an amino acid without involving transfer of the nitrogenous group or cleaving of a heterocyclic ring, turd the first to direetly implicate peroxidase.

P'eroxidase activily of sugareane leaves has shown a striking inverse: maltionship) with surose romtent $(1,2)$. However, even if one considers that all known roles of peroxidase ale being assuned by the sugateane lepplesculative, no rlear comestion can yel be druwn between peroxidase activity and surrose conlont. The relationship must certainly bo an indirect one and will have to await additional findings for its ultimate charification.

\section{SUMMARY}

A study was made of the distribution and properties of peroxidase in sugareane. The enzyme was extracted with phosphate buffer (pH 7.0) from freeze-duied tissues which had been ground to puss a 60 -mesh screen. Peroxidase was assayed spectrophotometrically at $430 \mathrm{~m} \mu$, the procedur: being based upon the formation of purpurogallin in a loffered solution of hydrogen peroxide, enzyme, and pyrogallol.

Fractionation of cane extracts with anmonim sulfule showed that proxidase is mecipitated between 50- and 70-percent saturation. The richest source of this enzyne was meristenuatic tissue, whereas grentest spesific activity was recorded with preparations from leaves +6 and +7 , and from sheaths +6 and +7 .

Preparations of peroxidase were not affected by dialysis against distilled water, but cousiderable aclivity loss was experienced within 2 days following preparulion. Refrigeration did not help preserve the enzyme. Aclivity of the preparations wa: totally lost after boiling for 5 minutes. However, much of the activity returned upon standing, a property also known for horserndish peroxidase.

Sugarcane peroxidase acted upon a number of substrates, including orthorresol, hydroquinone, catechol, pyrogullol, benzidine, analine, trypto- 
phane, guaiacol, and gum arabic. Optinum $\mathrm{pH}$ for the standard reaction was about 7.3 , and optimum temperature was $36^{\circ} \mathrm{C}$. Apparent $K_{m}$ was $2.5 \times 10^{-3}$ mole of pyrogallol per liter. Maxinum velocity was obtained with 1 mole of hydrogen peroxide per milliliter of digest. Under standard conditious, cane peroxidase maintained a zero-order reastion for about 2 minutes.

Peroxidnse was moderately inhibited by ealeium, manganese, and zine, each at a consentration of $1.0 \mu$ mole/ml. of digest. Jodide stimulated the

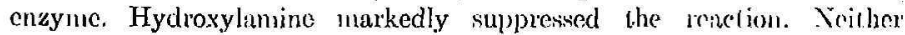
thiourea nor an excess of peroxide (180 $\mu$ moles/ml. of digest) russed inhibition, although the latier substances, as does hydroxylamine, greatly retard borsoradish petoxidase.

Caue peroxidase behaves like other plant peroxidases in that several enzyme-peroxide complexes are formed prior to oxidation of the electrondonor molecule. This reaction sequence was readily uncoupled with ascorbic acid. The velocity constant for the formation of the initial enzyme-substrate complex, $K_{1}$, was $0.13 \times 10^{7} \mathrm{M}^{-1} \times$ sec, $^{-1}$ at $20^{\circ} \mathrm{C}$. The velocily constant lor the oxidation of the donor molecule, $K_{4}$, was $0.46 \times 10^{6} \mathrm{M}^{-1} \times$ ser. -1 at $20^{\circ} \mathrm{C}$.

Known roles of plant peroxidases were bricfly reviewed.

\section{RESUMEN}

Se hizo un estudio de la distribución y las propiedacles de la peroxidasa en la caña de azúcar. La enzina se extrajo usando un fosfato con un pH de 7.0, como agente amortiguador, de tejidos congelados y disecados que se maceraron y pasiron por una criba de malla número 60. Se analizó la. peroxidasa mediante el procedimiento espectrofotométrico a $430 \mathrm{~m} \mu$, a base de la formación de purpurogalina (en una solución amortiguada cle peróxido de hidrógeno, enzina y pirogalol. Al fraceionarse los extractos de caña con sulfalo anónico, la jeyoxidasa se precipitó a una salurarion de 50 a 70 por riento. La nús rica fuente de est anzima fue el tejido meristemático, mientrus que la mayor actividad específica tuvo lugar en las preparaciones hechas con las hojas $+6 y+7, y$ las yaguas $+6 y+7$.

La acción dializadora no afectó las preparaciones de peroxidasa en presencia de agu destilada, aunque sí redujo su actividad considerablemente a los dos díus de haberse hecho las preparaciones. La refrigeración no ayudó a proservar In enzima. La actividad de las preparaciones cesó lotalmente después de hervir por 5 minutos. Sin enbargo, la actividad se reaundó pastaulo ulgín tienpo, mopiedad que fambién poses la peroxidasa del rábuno piounfe.

La peroxidasa de la caña de azúcar actúa sobre numerosos sustratos que incluyen el orto-cresol, la hidroguinona, el catecol, el pirogalol, la bencidiua, 
la analina, el biptofano, el guayacol y la goma arábiga. El pH óptimo para la reacción "stándard" fue de alrededor de 7.3 y la tempernlura óptina de $36^{\circ} \mathrm{C}$. La constante Michaelis $(K m)$ fue $2.5 \times 10^{-3} \mathrm{~mol}$ de pirogalol por litro. La velocidad máxima se obtuvo con $1 \mu \mathrm{mol}$ de peróxido de hidrógeno por mililitro de digesio. 13ajo condiriones normales, Ia peroxiclasa mantuvo una reacción de orden-cero en unos 2 uninutos.

La peroxidasa fue inhibida moderadamente por el caleio, el manguneso y el zinc, a concentraciones de $1.0 \mathrm{mmol} / \mathrm{ml}$. de digesto. Ll yoduro estimuló la enzina. Ia hidroxilamina redujo la reacción matrademente. Ni la tiurea

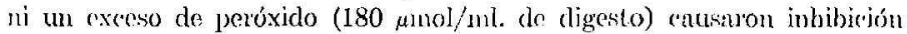
nguma, umeque esas mismus suslancias, al igual que la hidoxilamina, retardan grandencnte la peroxidasa del ríbano picante.

La peroxidasa de la cuña actúa de igual manera que las peroxidasas de otras planitas, fornando varios couplejos de enzinta-peróxidos antes de la oxidación de la molécula que provee el electrón. Essta secuencia reactiva se desconectó xápidamente con el ácido ascórbico. La constante de velocidad para la tormación del complejo inicial de la enzinu-sustrato, $K_{1}$, fue $0.13 \times 10^{7} \mathrm{II}^{-1} \times$ sec: $^{-1}$ i $20^{\circ} \mathrm{C}$. La constante de velocidad para la oxidación de la wolécula proveedora, $K_{1}$, fuc $0.46 \times 10^{5} \mathrm{M}^{-1} \times \mathrm{sec}^{-1}$ a $20^{\circ} \mathrm{C}$.

Se hizo un ligero análisis del payd rue descmpeñan las peroxidasas en las plantas.

\section{LITERATURE CITED}

1. Alexander, A. (i., Suerose-en\%yme lelafionships in immefure sugarenue ns aflectod by varying levels of nitrate and potassium supplied in sand vulture, J. Algr. Univ. P.R. 48(3): 165-231, 196t.

2. -.-., Clunges in leaf sugar content and curyme activity of sugurcune following foliar application of indole-3-acetic teid, $2,-1$-dichlorophenoxyacetic ncid and naleic ligdrazide, of. L gr. Univ. P.R. $40(1): 1-34,1465$.

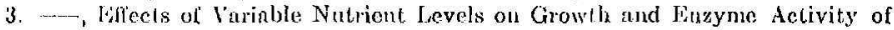
Ciuliflower; Thesis submitled to the Facully of the Gatuale sehool of the Universily of Maryland in partial fullfilment of yeduixements ior the degree of I ockor of Philosophy, 1060.

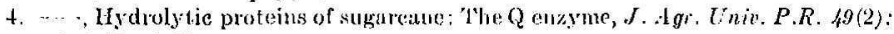
$170-203,1965$.

5. -.., Hydrolytic proteins of sugurcune: The acid invertases, $J$, I $g$. Unin. P.R. 49(3): $287-307,1965$.

6. Brown, J. C., and Steinberg, R. A., Iron and eopper enzymes in lcaf lamina of lobaces when deficient in micronulyents or grown on calcneous and organic soils, Plant Phissiol. 29: 488-94, 1952.

7. J3rown, J. C., and Jendricks, S. B., Enzymalie aefivilies as indieations of copper and iron defieieneies in plunts, Plant. Physiol. 27: 651-60, 1952.

8. Cecil, IR., and Ogsion, A. (i., Determination of sedimentation and dithsion comstaulit of horae-radisl peroxidase, Biochem. J. 49: 105-6, 1951.

9. Chanes, B3., The properties of the enzyne-substrate compounds of peroxidase 


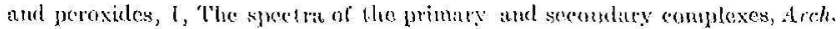
Biochem. 21; -116-30, 19-19.

10. - ..., The enyyne-substrate eompounds of horserudish peroxidase and peroxides, II, Kineties of formation and decomposition of the primary and serondury complexes, Arch. Biochem. 22: 221-52, 1919).

11. --.-, The properties of the cmayne-substrate compunuds of horse-radish and lacto-peroxiclase, Science 109: 20:1-8, 1949.

12. - - in Sumner, J. B., and Myrback, K., The Enaynes; chitpter 5for, Acudomic Press, New York, N.Y. \&: -128-53, 1951.

13. Chante, 13., and Fergusen, 1R. R., iu .Mrlilroy, W. D., itnd (dass, 13., Symposium on the Mechanism of Linyme Action, Johns Hopkins l'ress, I3altinore, Md., 105.

14. Chamee, B., and Machly, A. C., Assily of calalases and peroxidases, Methods in Enzlmol 2: $764-\overline{5} 5,1955$.

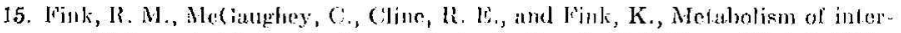
mediale pycimidine resluefion produets in vitro, J. Biol. Chem. 218: 1-8, 1950.

16. Fruton, d. S., and Simmonds, St., General Biochemistry, 2ucl. erl., Jolnu Wiley \& Sous, New Yon'k, N.Y., p. 3ił, 1963.

17. George, P., is Green, D. 1:., Gurtents in Binchemical Researeh, Interseienee Publishers, New York, N.Y., 1950.

18. Halevy, A. H., Inverse etfect of gibloctelliu and Amo-16ils on growth, ealalase, and peroxidase activity in cuenmher seedlings, Frperentia $18: 7+6,1062 a$.

19. --- Interaction of growth-returding componnds and gibberellin on iudolencelic acid oxidase and peroxidase of cucundser seedlings, Plant Physiol. 38: 731-7, 1063 .

20. Jones, M. li., and sipector, L., The paltway of carbonate in the hiessul hesis of carbarnyl phosphate; J. Biol. Chem. 235; 2897-901, 1960.

21. Keilin, 1), and Mamn, 'L., Hematin compunnd of peroxidise, Proc. Rou. Soc. London, 198B: 119-33, 1937.

22. Keilin, I., and Fartree, F. F., Properties of raltatise: Chtalysis of coupled oxida tion of ileohols, Biochem. J. 39: 293-301, 19+46.

23. Lukens, L. N., and Buchanan, J. M., Further intermediates in the biosyuthesis of inesinic acid de novo, $f$. Amer. Chem. Soe. $79: 1511-13,1957$.

2.t. Neislur, A., Metabolism of glutamine, Physiol. Revs, 36: 103-27, 1956.

25. Mazelis, M., and Jngraham, I. J., The pyricloxal phosphate-dependent oxidntive decarboxylation of methionine by peroxidase, Ir, Indentifieation of 3-methylthiopropionamide as a product of the reaction, I. Biol. Chem. 237(1): 100-13, 1962 .

20. --, The prridoxal plosphate-dependent oxidative decarboxylation of methionine by peroxidase, 1, Characteristics and properties of the renetion, $J$, Biol. Chem, 287: 10-1-8, 1962 .

27. MoCune, J). C., Multiple peroxidase in corn, .1 nn. A.Y. Acall. Sci. 94: 723-30, 1961.

28. Monselise, S. P., and Halevy, A. H., Effecis of gibberellin a id Amo-1018 on growth, dry matter accunulation, chlorophyll content, and peroxidase activity of cilrus seedlings, Amer. J. Bol. 40: 409-12, 1962.

29. Neilands, J. B., and Stumpf, P. K., Outlines of Enzyme Chemistry, John Wiley \& Sons, Ine., New York, N.Y., p. 98, 1964.

30. Preiss, J., und Handler, P., Biosynthesis of diplosphopyridine nucleotide, II, Enzymatic uspeels, J. Biol. ('Hem. 239: 493-500, 1058.

31. P'ur, $\lambda$., Rageneration of plant peroxidases, Biochem. Z. 921: 19-25, 1950. 
32. Rabinowil\%, J. C., and Pricer, W. J., Jr., Purine fernentution by Clostrilium cylindrospernm, 1X, t-urefdr-5-indazolentboxy arial, J. Biol. Chem. 218: 180200,1050 .

33. Ray, P. M., Destruetion of uuxin, Ann. Rev. Plant Physiol. 9: 81-118, 1958.

34. Sumner, J. B., and Somers, G. T., Chemistry and Methods of Linzymes, 3d. ed., Academic Press Inc., Publishers, New York, N.Y., p. 220, 1953.

35. Sutherlnud, E. W., Cori, C. F., Haynes, R., and Olsen, N. S., Purification of the hyperglycenic-glycogenolytic factor from insulin and from gastric mucosa, J. Biol. Chem. 180: 825-37, 1949.

36. Theorell, H., lioversible splitting of a peroxidase, Arkiv. Kemi, Mincral Geol. 14R: 1-3, No. 20, 1940.

37. - - Molectiar weight of erystalline horse-radish peroxiduse, Arkiv. Kemi, Wineral Qcol. 15B:1-4, No. 2t, 1942.

38. --.-, in Sumner, J. B., and Myrback, K., The Fingymes, rhipter 56B, Academic Press, Now York, N.Y., 1951.

30. Willstalter, R., and Stoll, A., Peroxiclases, Ann. Chem. 4tis: 21. 61, 1018.

40. Willstatter, R., and Pollinger, A., L'ernxidise, III, Ann. ('hem. 430: 209-319, 1023. 